Philip Doty

University of Texas at Austin

Austin, TX, USA

\title{
LEARNING FROM FICTIONAL CHARACTERS: AN INFORMATION BEHAVIOR PERSPECTIVE
}

\begin{abstract}
Reading fiction is an important information behavior, but systematic study in our field about fiction has been sparse. This paper is part of continuing research about how fiction is informative. It reviews work about the ontological status of literary characters and how they can affect and inform us, especially in creating and contesting social boundaries, based in part on a small empirical study $(n=8)$ of adult readers' reading as adolescents. Such work helps us to understand important elements of people's information behavior too often ignored.
\end{abstract}

\section{Introduction}

Philosopher and linguist Emar Maier recently asked whether a novelist telling a fictional story is a liar (2020). While such a question might be dismissed as inconsequential, a closer look offers insight valuable to information science about information behavior. An important point the essay makes is that statements in fictional works are "not straightforward instances of assertions at all" (4). What are they if not assertions? Fictional statements, in philosophy, are usually studied in two ways: semantic approaches, which identify such statements as shortened articulations of more complex circumstances, or pragmatic approaches, which assert that fictional statements are of an entirely different type than ordinary assertions. The pragmatic holds that fictional statements are radically different sorts of speech acts than ordinary statements, and this view is the one most widely held in philosophy and linguistics. Proponents of the pragmatic maintain that the important difference between lies and "made up" stories is that the reader is invited, even compelled, to an imaginative act, to enact our interpretive powers in a different way than simply judging the veracity of statements about some state of affairs.

According to this pragmatic perspective, novelists (and poets, playwrights, game designers, movie directors, and other creators of fictive works) cannot lie since the imaginative speech acts that constitute fiction adhere to different norms, aim to have different effects, and are intended for different purposes than ordinary statements subject to truth conditions. The fictional work's intention is not to deceive but rather to reveal, using the imagination, interpretive powers, emotional and intellectual engagement, and other gifts of the reader. Maier, citing a commonplace in literary and philosophic studies, concludes his essay by noting that, "on the one hand, the fiction author, like the liar, tells known falsehoods, but on the other hand, she thereby creates fictional truths" (7). How that happens, in fact, matters to information science's attempts to better understand and describe information behavior. This paper focuses on how we learn from characters in fictive works, noting the results from a small empirical study of how reading fiction informs us, especially about social boundaries.

\section{Information Science's Blinkered View of Fiction}


Donald Case and Lisa Given, in the fourth edition of Looking for Information (2016), ask, "Must information be true?" (66). It is fair to say that our field has generally held that information must be "true" (however defined) to be informative. Case and Given show our field's strong "bias against entertainment" (127), stemming from an affirmation of people as thinking beings, primarily rational, thereby distinguishing us from other sentient creatures. Our field has focused on "utilitarian behaviors" (129), especially the information behaviors of scientists, engineers, and other professionals, dismissing reading as mere "decoding" (Ford 2015, 24) rather than seeing it as a complex, multi-faceted, and social interpretive act (e.g., McKechnie et al. 2007, 193). The study of fiction in information science is uncommon in the field, with some important exceptions, as briefly discussed in Broussard \& Doty (2016) and Doty \& Broussard (2017).

Among the reasons why are the genesis of information science around the time of World War II (although the field of information studies is much older) and an often conceptually confusing obsession with the concept of "information." For example, Farkas-Conn narrates how, as the American Documentation Institute became the American Society for Information Science in 1968, a major purpose of the Association was to understand "the properties and behavior of information" $(1990,199)$. Burke notes a strong "faith in the possibility of a science of information" $(2007,26)$, while Shapiro discusses a movement from "the information scientist as a scientific information specialist to talking about a science of information" $(1995,385)$, and Burke (1994, 190 et passim) on information science as an information system for science. We all know the almost hegemonic influence of concepts such as:

- Shannon's information theory

- Wiener's cybernetics

- Decision-making

- Reduction of uncertainty

- Problem solving

- The utilitarian

- So-called "information needs"

- Information retrieval and information seeking

- The study of "conduits" for information and communication.

While readers certainly learn from reading fiction, they do not usually read it to "retrieve information," thus, such reading is generally not part of our field's understanding of information seeking, perhaps the major focus of information behavior research recently.

In fact, fiction often reminds us of what we do NOT know, of what puzzles and confuses us. Among the techniques for doing so are paratextual frames such as authors' prefaces, authors' direct comments to readers in the text, long-standing and post-modern techniques of shattered temporalities, unreliable narrators, conflicting views on what occurred, erosion of the purported realistic mode, and more. Especially important is fictive works' ability to emphasize how our lives are mundane, commonplace, and predictable, but also mysterious, even opaque to our most concentrated efforts to understand, especially because those people we think we know best are themselves mysteries to us (Chalk 2016, Dawson 2016, Kaplan 1992, Martin 2015).

\section{Some Results of the Empirical Study on How Literary Characters Inform Us}


Broussard \& Doty (2016) and Doty \& Broussard (2017) report on a small empirical study exploring how eight adults used fiction they read as adolescents as a "roadmap" for living, using semi-structured interviews for data collection (Weiss 1995) and thematic sorting for data analysis (Braun \& Clarke 2006). The study clearly showed the phenomenological complexity of the role of reading in our informants' lives, then and now, and it underscored how five other fields' investigation of reading fiction can enlighten information science's study of information behavior. The five fields were philosophy, literary studies, psychology, entertainment studies, and education. In this abbreviated format, I will share only some of the respondents' insights into how fictive works informed them, especially through the use of literary characters specifically how fiction contributed to their affirming and transgressing social boundaries.

In a recent review of Character: Three Inquires in Literary Studies (2019) by scholars Toril Moi, Rita Felski, and Amanda Anderson, Lee Konstantinou, recalling Maier (2020), focuses on how literary characters can affect us when we know they are not real, i.e., are only patterns of marks in a text or, by extension, images in a video game or movie. How are characters worth taking seriously in any moral or emotional sense? Konstantinou notes how many commentators ridicule those who regard fictive characters as in any way real, realistic, or capable of "showing" us anything, e.g., famed novelist William Gass's insistence that a fictive character is only "'the noise of his name," nothing like a living creature. Such a dismissal of literary characters as real is an important part of the structuralist tradition and other movements such as le nouveau roman of Alain Robbe-Grillet, Marguerite Duras, and others. In contrast, equally eminent thinkers, including Martha Nussbaum (e.g., 1990, on informing the moral imagination) and Stanley Cavell (e.g., 2003, on knowledge and skepticism in Shakespeare), insist that literary characters can teach us "life lessons."

Can fictive characters be explicit fabrications in narrative forms but also means for thinking of them as individuals with histories, relationships, and inner lives like our own? Konstantinou answers in the affirmative, relying on the work of John Frow (2014) that fictive characters are "'ontological hybrids," a union of structures of narrative form and references to persons we can believe as real. And, as Konstantinou notes, what is valuable in this hybrid form is not just characters with whom we can identify and thereby learn from, but also characters with whom we do NOT wish to identify and from whom, in fact, authors separate us using a variety of narrative and emotive means, e.g., Meursault in Camus' L'Étranger or Dostoevsky's Underground Man in Notes from Underground (p. 5).

One of the most famous exchanges about the status of literary characters involved Colin Radford and Michael Weston in 1975, as both engaged the question: "How can we be moved by the fate of Anna Karenina?" Radford entertains many explanations, dismissing them all on one ground or another, concluding that "our being moved in certain ways by works of art, though very 'natural' to us and in that way only too intelligible, involves us in inconsistency and so incoherence" (p. 78). Weston finds Radford's "conclusion" completely wrong-headed, asserting that Radford "ignores the fact that our responses to characters in fiction are responses to works of art" (p. 81) - taking part in a shared interpretive act with other readers, watchers, and reactors to fictive works. Responses to literary characters are in the context of the "kind of object [literary] works are," helping us to ask questions about how to live and whether our lives possess any significance, citing the work of Peter Winch. Perhaps most importantly, Weston concludes that "the importance of art to us is one way this concern to make sense of our lives appears" (p. 92).

Literary and other scholars studying the reading of fictive works emphasize how such works help us create and transgress boundaries in our social worlds (e.g., Bettelheim 1975; 
Buckingham 1993; Carroll 1996; Finders 1997; Radway 1991). Table 1 gives a brief list of responses from our informants about how their reading of fictive works as adolescents informed them about such boundaries and continues to do so.

\section{Table 1 AFFIRMING AND TRANSGRESSING SOCIAL BOUNDARIES}

Respondent (R) and comment

- $\quad$ R6 Went to parochial school, used the List of Condemned Books and Movies, "I was all over the place trying out different genres, a time to just sample everything that was out there, especially if it was on that [forbidden] list!"

- R1 Was forbidden by family members to read books about "witchcraft, specifically Harry Potter"

- R2 Looked for and secretly shared books "with sex in them," hiding them from their parents

- R4 "It was so astounding to read books about these topics . . . a girl having her first period .... and a young couple that are either contemplating or do have sex, they're probably in high school. I thought it was wonderful I could read about that ... . realistic teen angst."

- R5 discussed Flowers in the Attic and its forbidden theme of incest

- R1 In retrospect, experienced discomfort with the "sexist remarks" and tropes in works of Robert Heinlein's initially enjoyed

- R4 Black Like Me, was "horrified by it"

- R8 The Bridge to Terabithia - a major character died, "we had just had someone in our class pass away at the same time .... [making coping with the death] more difficult just because it [the book] brought up what had just happened and brought up memories of that person."

- R7 "I think there were books that probably opened up topics I hadn't thought much about before, and so were probably informative in one way or another," e.g., was deeply impressed by Kaye Gibbons [Ellen Foster] "a dark harrowing story of child abuse"

- R4 Really loved Grapes of Wrath, it changed "me about people who lived in poverty because I didn't know anybody who lived in poverty. I mean I wasn't friends with the poor kids." As the family's financial circumstances improved, "I was even a little bit arrogant with the poor kids who got on the bus .... That book really gave me an awareness of those kids who didn't have opportunities that I did, even though mine weren't grand."

- R1 In Animal Farm, "As soon as the underdog is no longer the underdog, they become everything they hate ... Y You could become a new person and still make all of the same old mistakes."

- R3 Influence of Holocaust memoires and Mein Kampf was strong and lasts until today

- R4 Loved In Cold Blood and Helter Skelter, "gave you insight into the killer's mind . . really humanized the victims so that you felt awful, and you were so happy it wasn't you, but you were so sad for the victims."

\section{Conclusion}

As a field information science, and the larger umbrella of information studies, is not merely a handmaiden to science as it was first envisioned in the early years after WWII, but a fully computational, social scientific, and humanistic field. And research into the complex information behaviors of reading fiction demonstrate what we have to contribute. The respondents in our small empirical study showed deep and enduring links between their reading of fictional works and the research in other fields about the value of reading fiction, especially between literary theory and its exploration of social boundaries. What we see is that the literary 
art, the making up of stories (whether in novels, movies, plays, operas, games, short stories, songs, TV series, and more), invites us to a well-recognized mode of shared interpretive action. That action involves our learning, our changing because of our participation in the action. To imagine that such action, such change is not demonstration of being informed seems almost unthinkable.

\section{References}

Anderson, Amanda, Felski, Rita, \& Moi, Toril. (2019). Character: Three inquiries in literary studies. Chicago: University of Chicago Press.

Bettelheim, B. (1975). The uses of enchantment: The meaning and importance of fairy tales. New York: Random House

Braun, Virginia, \& Clarke, Victoria. (2006). Using thematic analysis in psychology. Qualitative Research in Psychology, 3(2), 77-101.

Broussard, Ramona, \& Doty, Philip. (2016). Toward an understanding of fiction and information behavior. Annual Conference of the Association for Information Science \& Technology. Copenhagen, Denmark.

Buckingham, David. (1993). Reading audiences: Young people and the media. Manchester, UK: Manchester University Press.

Burke, Colin. (1994). Information and secrecy: Vannevar Bush, Ultra, and the other Memex. Metuchen, NJ: Scarecrow Press.

Burke, Colin. (2007). History of information science. Annual Review of Information Science and Technology (Vol. 41, 3-53). Medford, NJ: Information.

Carroll, N., (1996). The paradox of suspense. In P. Vorderer, H.J. Jorrgen-Wulff, \& M. Friedrichsen (Eds.), Suspense: Conceptualizations, theoretical analyses and empirical explorations. Hillsdale, NJ: Lawrence Erlbaum.

Case, Donald O., \& Given, Lisa. (2016). Looking for information: A survey of research on information seeking, needs, and behavior ( $4^{\text {th }}$ ed.). Bingley, UK: Emerald Publishing.

Cavell, Stanley. (2003). Disowning knowledge in seven plays of Shakespeare (2 $\left.{ }^{\text {nd }} \mathrm{ed}.\right)$. Cambridge, UK: Cambridge University Press.

Chalk, Bridget. (2016). [Review of the book The Value of the Novel, by Peter Boxall]. Studies in the Novel, 38(3), 384-385.

Dawson, Paul. (2016). From digressions to intrusions: Authorial commentary in the novel. Studies in the Novel, 48(2), 145-167.

Doty, Philip, \& Broussard, Ramona. (2017). Fiction as informative and its implications for information science theory. Annual Conference of the Association for Information Science \& Technology. Crystal City, VA.

Farkas-Conn, Irene S. (1990). From documentation to information science: The beginnings and early development of the American Documentation Institute - American Society for Information Science. New York: Greenwood Press.

Finders, M. J. (1997). Just girls: Hidden literacies and life in junior high. New York: Teachers College Press.

Ford, Nigel. (2015). Introduction to information behaviour. London: Facet Publishing.

Frow, John. (2014). Character \& person. Oxford, UK: Oxford University Press. 
Kaplan, Amy. (1992). The social construction of American realism. Chicago: University of Chicago Press.

Konstantinou, Lee. (2020, January 13). The noise of our names: On Character: Three inquiries in literary studies. Los Angeles Review of Books.

https://areviewofbooks.org/article/the-noise-of-our-names-on-character-three-inquiries-inliterary-studies/

Maier, Emar. (2020, January 13). Making up stuff. Aeon. https://aeon.co/essays/how-to-tellfact-from-fiction-in-fiction-and-other-forms-of-lies

Martin, Linda. (2015). Elegy and the unknowable mind in Jacob's Room. Studies in the Novel, 47(2), 176-192.

McKechnie, Lynne (E.F.), Ross, Catherine Sheldrick, \& Rothbauer, Paulette. (2007). Affective dimensions of information seeking in the context of reading. In Diane Nahl \& Dania Bilal (Eds.), Information and emotion: The emergent affective paradigm in information behavior research and theory (pp. 187-195). Medford, NJ: Information Today.

Nussbaum, Martha C. (1990). Love's knowledge: Essays on philosophy and literature. Oxford, UK: Oxford University Press.

Radford, Colin. (1975). How can we be moved by the fate of Anna Karenina? Part I. Proceedings of the Aristotelian Society, Supplemental Volumes, 49, 67-80. Stable URL: http://www.jstor.org/stable/4106870

Radway, Janice A. (1991). Reading the romance: Women, patriarchy, and popular literature. Chapel Hill, NC: University of North Carolina Press.

Shapiro, Fred R. (1995). Coinage of the term information science. Journal of the American Society for Information Science, 46(5), 384-385.

Weiss, Robert S. (1995). Learning from strangers: The art and method of qualitative interview studies. New York: Simon \& Schuster.

Weston, Michael. (1975). How can we be moved by the fate of Anna Karenina? Part II. Proceedings of the Aristotelian Society, Supplemental Volumes, 49, 81-93. Stable URL: http://www.jstor.org/stable/4106870 